\section{Pacific Northwest}

National Laboratory

Operated by Battelle for the

U.S. Department of Energy

\title{
Analysis of IECC2003 Chiller Heat Recovery for Service Water Heating Requirement for New York State
}

D. W. Winiarski

August 2004

Prepared for the U.S. Department of Energy under Contract DE-AC06-76RL01830 


\title{
DISCLAIMER
}

This report was prepared as an account of work sponsored by an agency of the United States Government. Neither the United States Government nor any agency thereof, nor Battelle Memorial Institute, nor any of their employees, makes any warranty, express or implied, or assumes any legal liability or responsibility for the accuracy, completeness, or usefulness of any information, apparatus, product, or process disclosed, or represents that its use would not infringe privately owned rights. Reference herein to any specific commercial product, process, or service by trade name, trademark, manufacturer, or otherwise does not necessarily constitute or imply its endorsement, recommendation, or favoring by the United States Government or any agency thereof, or Battelle Memorial Institute. The views and opinions of authors expressed herein do not necessarily state or reflect those of the United States Government or any agency thereof.

\author{
PACIFIC NORTHWEST NATIONAL LABORATORY \\ operated by \\ BATTELLE \\ for the \\ UNITED STATES DEPARTMENT OF ENERGY \\ under Contract DE-AC06-76RL01830
}

Ty 


\section{Analysis of IECC2003 Chiller Heat Recovery for Service Water Heating Requirement for New York State}

D. W. Winiarski

August 2004

Prepared for

the U.S. Department of Energy

Office of Building Technologies

under Contract DE-AC06-76RL01830

Pacific Northwest National Laboratory

Richland, Washington 99352 


\section{Summary}

The state of New York asked the U.S. Department of Energy to evaluate the cost-effectiveness of the requirement for heat recovery for service water heating that exists in the 2003 International Energy Conservation Code to determine whether this requirement should be adopted into the New York State Energy Code. A typical hotel application that would trigger this requirement was examined using whole building simulation software to generate baseline annual chiller and service hot water loads, and a spreadsheet was used to examine the energy savings potential for heat recovery using hourly load files from the simulation. An example application meeting the code requirement was developed, and the energy savings, energy cost savings, and first costs for the heat recovery installation were developed. The calculated payback for this application was 6.3 years using 2002 New York state average energy costs. This payback met the minimum requirements for cost effectiveness established for the state of New York for updating the commercial energy conservation code. 


\section{Table of Contents}

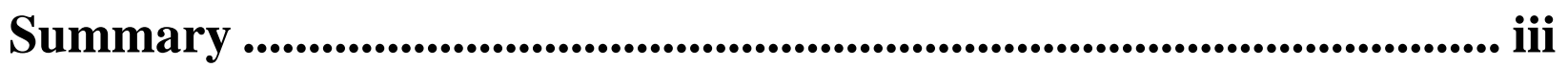

Background .....................................................................................................................

Applicable Buildings ...........................................................................................2

Analysis Methodology ......................................................................6

Development of DOE2.2 Building Model.........................................................6

Development of Service Hot Water Load Estimates .............................................

Base Building Simulation.......................................................................10

Condenser Heat Rejection and Service Hot Water Loads .................................... 12

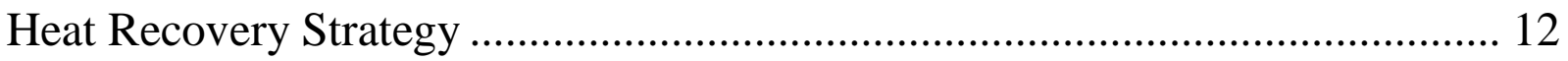

Impact on Chiller Performance....................................................................... 14

Impacts to Heat Rejection Equipment ............................................................ 14

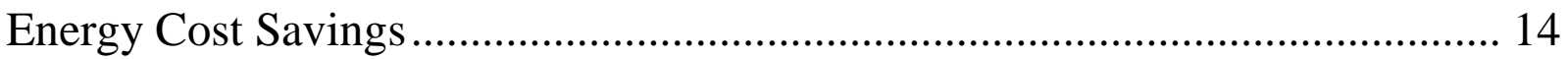

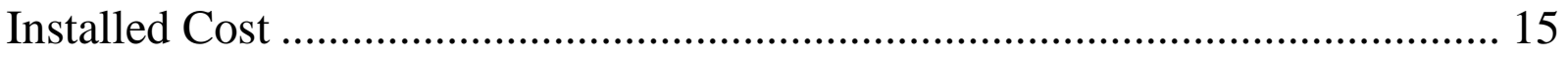

Estimated Payback …………………………………………………….... 15

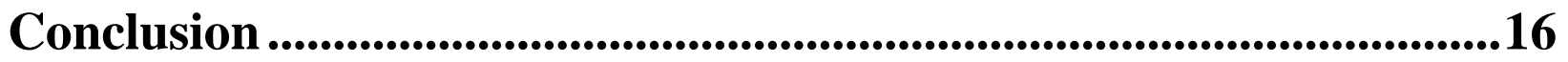

References .................................................................................17

Appendix A Design Parameters for Plate Heat Exchanger ...............20 Appendix B Estimated Costs for Heat Recovery System.....................23 


\section{Figures}

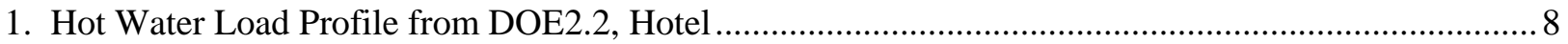

2. Electrical Energy Consumption for Base Hotel Building, by End Use. .......................................... 10

3. Natural Gas Energy Consumption for Base Hotel Building, by End Use.......................................... 11

4. Schematic of Service Heat Recovery System .................................................................................. 13

\section{Tables}

1. Aggregate Number of Building and Represented Floor Space for Buildings Operated 24 Hours per Day and Using Central Chillers (CBECS 1995) ....................................................................... 3

2. Minimum Cooled Floor Area for a Building with 400 tons of Cooling. .......................................... 3

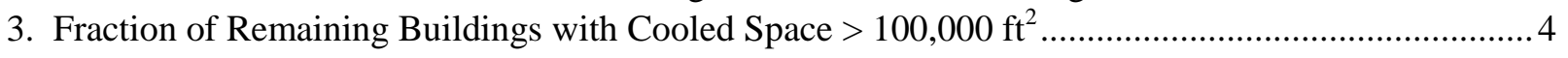

4. Estimate of Building Size for a 1,000,000 Btu/h Service Hot Water Load .......................................5

5. Building Simulation Model Details ........................................................................................ 7

6 Energy Consumption for Base Hotel Building, by End Use........................................................ 11

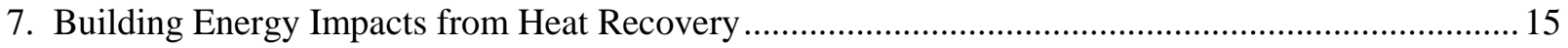

A-1. Design Parameters for Plate Heat Exchanger Systems (Haselego) .................................................20

A-2. Final Double-Wall-Vented Plate Heat Exchanger Specification Sheet used in Energy Savings .......21

B-1. Material, Labor, and Total Estimated Installation Cost for Heat Recovery System..........................23 


\section{Background}

The state of New York requested the U.S. Department of Energy evaluate the cost effectiveness of the requirement for condenser heat recovery for service water heating that exists in the 2003 version of the International Energy Conservation Code (IECC 2003) (herein referred to as IECC2003) using the 10-year payback economic criteria for the state of New York.

The heat recovery for service water heating requirement in the IECC2003 stems from a nearly identical requirement that exists in ANSI/ASHRAE/IESNA 90.1-2001 (ASHRAE 90.1-2001) as well as its predecessor, ANSI/ASHRAE/IESNA 90.1-1999 (ASHRAE 90.1-1999). The requirement is designed to encourage the use of condenser heat recovery from water-cooled air conditioning systems when a significant service water heating load exists that could benefit from the recovered heat. The IECC2003 requirement is shown below.

803.3.9 Heat Recovery for Service Water Heating. Condenser heat recovery systems shall be installed for heating or reheating of service hot water provided that the facility operates 24 hours a day, the total installed heat rejection capacity of water-cooled systems exceeds $6,000,000 \mathrm{Btu} / \mathrm{h}$ of heat rejection, and the design service water heating load exceeds 1,000,000 Btu/h.

The required heat recovery system shall have the capacity to provide the smaller of:

1) Sixty percent of the peak heat rejection load at design conditions; or

2) The preheating required to raise the peak service hot water draw to $85^{\circ} \mathrm{F}\left(29^{\circ} \mathrm{C}\right)$.

\section{Exceptions:}

(a) Facilities that employ condenser heat recovery for space heating or reheat purposes with a heat recovery design exceeding 30 percent of the peak water-cooled condenser load at design conditions.

(b) Facilities that provide $60 \%$ of their service water heating from site solar or site recovered energy or from other sources.

This document contains a limited analysis of the cost-effectiveness of this requirement based on a "typical" application in the state of New York. Because of the huge potential variation in building designs and uses for buildings with the characteristics defined above, no attempt is made to ensure that the requirement would always be cost effective, but rather to indicate whether or not a cost-effective implementation exists in a "typical" application that meets the above criteria. 


\section{Applicable Buildings}

The trigger criteria for this requirement are based on building hours of operation, total installed heat rejection capacity of water-cooled systems, and design service water heating load. The combination of these three items can be used to identify typical building applications. To identify the characteristic buildings for this study, the three criteria were applied to the 1995 Commercial Building Energy Consumption Survey (CBECS) building data set (EIA 1997), as described below, to subset that building sample to identify the "typical" applications in the U.S.

The first criterion examined is the requirement for 24-hour operation. While any commercial building can be used on a 24-hour basis, the most common buildings were expected to be hotel/motel, multifamily housing, inpatient health care (e.g., hospitals), some laboratories and industrial facilities, refrigerated warehouse, and some large retail buildings. In the subsetting of the CBECS data set, only buildings that reported 24 hour-a-day operation were examined (weekly hours of operation variable WKHRS6 in CBECS was equal to 168). This reduced the original building sample from 5766 buildings to 1103 buildings.

The second requirement is that they have over $6,000,000 \mathrm{Btu} / \mathrm{h}$ of heat rejection capacity of the watercooled systems. Approximately 15,000 Btu/h of heat is rejected per ton of cooling, so this indicates total cooling capacity near 400 tons. In most cases, this will indicate relatively large water-cooled chiller systems providing the available cooling for the building. The CBECS sample selection was further subset to include only buildings that reported the use of central chillers (CBECS Variable CHILLR6 equals 1). This further reduced the sample to 361 buildings encompassing a variety of building "types" [technically the "Principle Building Activity" (PBA) classification] used by CBECS. The number of buildings and total square footage of buildings by PBA is shown in Table 1.

The requirement for over approximately 400 tons of cooling was used to further subset the database. The minimum total capacity of a water-cooled system helps to identify the minimum building area that should be cooled by chillers in the building. To make use of this data, estimates of typical building square footage served per ton of cooling are used (Bell 2000). Because these are simply design rules of thumb, and may not be indicative of current or future new design, it is recognized that this will only provide an approximate building size estimate. However, this is expected to remove a large portion of the buildings, which would clearly be too small to engage the current IECC2003 heat recovery for service water heating requirement.

Table 2 shows the typical cooling intensities assumed by building type for the majority of buildings types shown in Table 1, as well as providing the approximate minimum building size that would be served by a 400-ton or larger cooling system using the sizing rules of thumb shown by Bell (Bell 2000). As can be seen, most buildings will be close to $100,000 \mathrm{ft}^{2}$ of cooled space before they are likely to require 400 tons of cooling capacity. For the purposes of this study, we subset the CBECS data further by requiring at least $100,000 \mathrm{ft}^{2}$ of building area be cooled in the sample. 
Table 1. Aggregate Number of Building and Represented Floor Space for Buildings Operated 24 Hours per Day and Using Central Chillers [EIA 1997 (CBECS data 1995)]

\begin{tabular}{|l|r|r|}
\hline Principal building activity & Number of Buildings & $\begin{array}{r}\text { Represented Floor } \\
\text { Space (sf) }\end{array}$ \\
\hline Education & 8 & 107985564 \\
\hline Enclosed shopping center/Mall & 1 & 8304000 \\
\hline Food services (restaurants) & 1 & 4152000 \\
\hline Health care (inpatient) & 136 & 1210545179 \\
\hline Health care (outpatient) & 6 & 27501650 \\
\hline Laboratory & 4 & 27490275 \\
\hline Lodging (hotel/motel/dorm) & 51 & 725700449 \\
\hline Nursing home & 8 & 97075113 \\
\hline Office/Professional & 95 & 757412437 \\
\hline Other & 2 & 80215500 \\
\hline Public assembly & 11 & 220030250 \\
\hline Public order and safety & 13 & 169349926 \\
\hline Retail (except mall) & 1 & 5868000 \\
\hline Service (except food) & 10 & 230147400 \\
\hline Strip shopping & 1 & 16118400 \\
\hline Vacant & 5 & 66577075 \\
\hline Warehouse (non-refrigerated) & 8 & 118103514 \\
\hline Grand Total & $\mathbf{3 6 1}$ & $\mathbf{3 8 7 2 5 7 6 7 3 1}$ \\
\hline
\end{tabular}

Table 2. Minimum Cooled Floor Area for a Building with 400 tons of Cooling.

\begin{tabular}{|l|l|r|r|}
\hline Building Type & Bell Classification & sf/ton & $\begin{array}{l}\text { Area Served by 400 } \\
\text { Ton Cooling } \\
\text { System (SF) }\end{array}$ \\
\hline Education & & 250 & 100000 \\
\hline $\begin{array}{l}\text { Enclosed shopping } \\
\text { center/Mall }\end{array}$ & 6.16 School Classrooms & 250 & 100000 \\
\hline Food services (restaurants) & 6.17 Dining Halls, Lunch Rooms & 175 & 70000 \\
\hline Health care (inpatient) & 6.09 Hospital Patient Rooms & 275 & 110000 \\
\hline Health care (outpatient) & 6.11 Medical Dental Centers Clinics & 275 & 110000 \\
\hline Laboratory & $6.10100 \%$ OA Labs & 200 & 80000 \\
\hline Lodging (hotel/motel/dorm) & 6.14 Motel/Hotel Public Spaces and & 363 & 145000 \\
\hline Nursing home & 6.15 Motel/Hotel Guestrooms & 275 & 110000 \\
\hline Office/Professional & 6.09 Hospital Patient Rooms & 350 & 140000 \\
\hline Other & 6.01 Offices, Commercial & 300 & 120000 \\
\hline Public assembly & 6.27 All Spaces (low range estimate) & 300 & 120000 \\
\hline Public order and safety & 6.18 Libraries/Museums & 300 & 100000 \\
\hline Retail (except mall) & 6.03, Police Stations & 250 & \\
\hline & 6.19 Retail Department Stores & & \\
\hline
\end{tabular}

Identification of remaining subset of the CBECS 95 buildings, where the cooled building area is greater than $100,000 \mathrm{ft}^{2}$, results in the data shown in Table 3. 
Table 3. Fraction of Remaining Buildings with Cooled Space $>100,000 \mathrm{ft}^{2}$

\begin{tabular}{|l|r|r|r|r|}
\hline Principal building activity & $\begin{array}{l}\text { Count of } \\
\text { CBECS } \\
\text { buildings } \\
\text { greater than } \\
\mathbf{1 0 0 , 0 0 0} \mathbf{f t}^{\mathbf{2}}\end{array}$ & $\begin{array}{l}\text { Fraction of } \\
\text { Remaining } \\
\text { Sample }\end{array}$ & $\begin{array}{l}\text { Represented } \\
\text { Floor Space } \\
\text { (ft }^{2} \text { ) }\end{array}$ & $\begin{array}{l}\text { Fraction of } \\
\text { Represented } \\
\text { Floor Space }\end{array}$ \\
\hline Education & 6 & $2.2 \%$ & 47185564 & $1.61 \%$ \\
\hline $\begin{array}{l}\text { Enclosed shopping } \\
\text { center/Mall }\end{array}$ & 1 & $0.4 \%$ & 8304000 & $0.28 \%$ \\
\hline Food services (restaurants) & 1 & $0.4 \%$ & 4152000 & $0.14 \%$ \\
\hline Health care (inpatient) & 112 & $41.8 \%$ & 1017163997 & $34.68 \%$ \\
\hline Health care (outpatient) & 3 & $1.1 \%$ & 16687000 & $0.57 \%$ \\
\hline Laboratory & 2 & $0.7 \%$ & 14532000 & $0.50 \%$ \\
\hline Lodging (hotel/motel/dorm) & 33 & $12.3 \%$ & 541006577 & $18.45 \%$ \\
\hline Nursing home & 2 & $0.7 \%$ & 52623400 & $1.79 \%$ \\
\hline Office/Professional & 76 & $28.4 \%$ & 587328037 & $20.03 \%$ \\
\hline Other & 2 & $0.7 \%$ & 80215500 & $2.73 \%$ \\
\hline Public assembly & 5 & $1.9 \%$ & 103274300 & $3.52 \%$ \\
\hline Public order and safety & 5 & $1.9 \%$ & 91004850 & $3.10 \%$ \\
\hline Retail (except mall) & 1 & $0.4 \%$ & 5868000 & $0.20 \%$ \\
\hline Service (except food) & 8 & $3.0 \%$ & 199205250 & $6.79 \%$ \\
\hline Strip shopping & 0 & $0.0 \%$ & & 0 \\
\hline Vacant & 4 & $1.5 \%$ & 57733000 & $1.97 \%$ \\
\hline $\begin{array}{l}\text { Warehouse (non- } \\
\text { refrigerated) }\end{array}$ & 7 & $2.6 \%$ & 106651414 & $3.64 \%$ \\
\hline Grand Total & $\mathbf{2 6 8}$ & $\mathbf{1 0 0 . 0 \%}$ & $\mathbf{2 9 3 2 9 3 4 8 8 9}$ & $\mathbf{1 0 0 . 0 0 \%}$ \\
\hline
\end{tabular}

As can be seen, the majority of the floor space in the remaining building sample is in three categories: Office/Professional, Inpatient Health Care, and Lodging.

Finally, it is important to consider the size of the water heating system in these buildings. The water heating system is required to have a peak size of $1,000,000 \mathrm{Btu} / \mathrm{h}$ for the requirement to be in effect. An estimate of the size of building for which this load exists can be made by looking at the typical service hot water (SHW) peak flows and temperature rise. The ASHRAE 1999 Applications Handbook (ASHRAE 1999) provides some useful data for office buildings and motel/hotel applications. Office buildings are reported to have maximum hourly use rates averaging 0.4 gal/person. Large motels (100 or more units) typically report maximum hourly usage of 4 gal/guestroom for personal water consumption. Food service, laundry, or hot water provided for pool heating are not included in this motel number. Laundry, while a significant hotel hot water load, is commonly done in the middle of the day or after checkout time and may be largely ignored in determining peak water consumption (George 2003, Meyer 2001).

The ASHRAE data can be thought of in terms of service units, where the service units in these examples are number of persons or number of guestrooms to be served by the water heating system. To determine the peak hot water load per square foot, we need to establish the number of service units per square foot. An example of how this is done is provided in DOE's Screening Analysis for EPACT Covered Commercial HVAC and Water Heating Equipment (DOE 2000) for several building types. Table 4 
shows service unit density, and subsequent water load for office and hotel buildings. A low inlet water temperature of $40^{\circ} \mathrm{F}$ and tank water temperature of $140^{\circ} \mathrm{F}$ were assumed for sizing purposes. The building area corresponding to a 1,000,000 Btu/h service water heating load is shown in the last column on the right.

Table 4. Estimate of Building Size for a 1,000,000 Btu/h Service Hot Water Load

\begin{tabular}{|c|c|c|c|c|c|}
\hline Building type & Service Unit & $\begin{array}{l}\text { Service } \\
\text { Units } \\
/ 1000 \text { sf }\end{array}$ & $\begin{array}{l}\text { Peak SHW } \\
\text { Flow } \\
\text { (gal/h per } \\
\text { service } \\
\text { unit) }\end{array}$ & $\begin{array}{l}\text { Peak } \\
\text { hourly } \\
\text { SHW Load } \\
\text { Btu/h/1000 } \\
\text { sf }\end{array}$ & $\begin{array}{l}\text { Building } \\
\text { Area/1,000,000 } \\
\text { Btu/h (sf) }\end{array}$ \\
\hline $\begin{array}{l}\text { Lodging } \\
\text { (hotel/motel/dorm) }\end{array}$ & guestrooms & 3.3 & 4 & 10890 & 91827 \\
\hline Office/Professional & person & 3.3 & 0.4 & 1089 & 918274 \\
\hline
\end{tabular}

This data for hotel and offices indicates that a hotel size of approximately 92,000 $\mathrm{ft}^{2}$ would likely have a peak hot water demand of approximately 1,000,000 Btu/h. An office building, even one operated 24 hours/day, would have to be closer to $920,000 \mathrm{ft}^{2}$ in size to have a similar peak hot water load. A hospital, while not shown in Table 4, would be expected to have hot water loads similar to, or somewhat greater than, that of a lodging facility.

The analysis suggests that a hotel greater than approximately $100,000 \mathrm{ft}^{2}$ in size represents a common application of the IECC heat recovery requirement. Inpatient hospitals may be even more common applications based on the data presented in Tables 1 through 3. Very large office buildings (approximately 1,000,000 $\mathrm{ft}^{2}$ in size) may also represent buildings where the requirement would be in force. However, a review of the CBECS data set suggests that such office buildings would be a smaller fraction of the applications. Of the 76 office buildings shown in Table 3 (representing 587 million $\mathrm{ft}^{2}$ of floor space), only 23 buildings were $920,000 \mathrm{ft}^{2}$ or bigger (174 million $\mathrm{ft}^{2}$ of floor space). However, given New York's large metropolitan population, it is important to not overlook this building category during implementation.

The remainder of this analysis will focus on application of condenser heat recovery in a large hotel building. 


\section{Analysis Methodology}

The analysis methodology here is to:

1) Develop a simplified model of a building of a size and application that would typically trigger the requirement as defined in the IECC2003.

2) Develop service hot water (SHW) usage and usage profiles for these buildings.

3) Estimate chiller heat rejection for these buildings based on simulated chiller usage.

4) Define strategy for chiller heat recovery.

5) Size heat recovery equipment for each strategy.

6) Estimate available annual service hot water heating energy avoided through use of heat recovery.

7) Determine avoided service hot water heating cost resulting from heat recovery.

8) Determine the impact to chiller performance and chiller electrical usage.

9) Determine additional operational cost for heat recovery.

10) Determine the potential for equipment downsizing.

11) Determine cost premium for heat recovery installation.

12) Determine simple payback for service hot water heat recovery.

These steps are outlined in the following pages of the report. Further details may also be found in the Appendices.

\section{Development of DOE2.2 Building Model}

A whole building simulation was created for the hotel building using DOE2.2 (Hirsch 2003). The hotel building is composed of two identical hotel wings, each with a total floor area of approximately 100,000 $\mathrm{ft}^{2}$, and three stories tall. ${ }^{\mathrm{a}}$ The individual wings of the building prototype use five building zones per floor consisting of a core zone and four perimeter zones. The area per floor is $33,856 \mathrm{ft}^{2}$. Only one wing of the building is actually simulated. The building simulated is a simple rectangle in shape, with each floor 368 $\mathrm{ft}$ in length and $52 \mathrm{ft}$ in width. The long axis of the building is oriented east-west.

The perimeter of the building is assumed to consist largely of individual rooms, approximately $20 \mathrm{ft}$ in depth. Envelope and heating, ventilation and air conditioning (HVAC) characteristics were developed

\footnotetext{
${ }^{a}$ Although rule of thumb cooling load and sizing guidelines suggested a 100,000 $\mathrm{ft}^{2}$ hotel building, initial building loads analysis for that size building did not indicate a heat rejection of $6,000,000 \mathrm{Btu} / \mathrm{h}$ for this location and with the assumed building load assumptions. The building size was then doubled for this analysis to be representative of current construction practices.
} 
from requirements found in ASHRAE 90.1-2001. ASHRAE 90.1 provides an alternate compliance path for in the IECC2003, and it was felt to be more representative of the code used in larger commercial buildings. Lighting power densities were developed based on those found in the IECC2003 currently being considered for adoption by the state of New York.

A central plant, consisting of a single screw chiller and central hot water boiler per building wing serve the HVAC needs of the building. Individual fan coil units are assumed to serve the individual rooms and other spaces. Other building statistics are shown in Table 5, below.

Table 5. Building Simulation Model Details

\begin{tabular}{|c|c|}
\hline General Building Info & \\
\hline Building type & Hotel \\
\hline Floor area & $101,568 \mathrm{ft}^{2}$ \\
\hline Number of stories & 3 \\
\hline Shape & Rectangular \\
\hline Length & $368 \mathrm{ft}$ \\
\hline Width & $92 \mathrm{ft}$ \\
\hline Floor-to-floor height & $13 \mathrm{ft}$ \\
\hline Floor-to-ceiling height & $9 \mathrm{ft}$ \\
\hline Window-wall-ratio & $30 \%$ \\
\hline Perimeter area fraction & $49.6 \%$ \\
\hline Core area & $50.4 \%$ \\
\hline Building peak occupancy & 551 persons \\
\hline Hotel rooms & 335 rooms \\
\hline Building misc eq. load & $0.266 \mathrm{Btu} / \mathrm{h}-\mathrm{ft}^{2}$ \\
\hline \multicolumn{2}{|l|}{ Envelope Characteristics } \\
\hline Wall type & Mass \\
\hline Wall U-factor & $0.088 \mathrm{Btu} / \mathrm{h}-\mathrm{ft}^{2}-{ }^{\circ} \mathrm{F}(\mathrm{R}-9.4 \mathrm{ci})$ \\
\hline Roof -type & Built up \\
\hline Roof R-value & $0.053 \mathrm{Btu} / \mathrm{h}-\mathrm{ft}^{2}-{ }^{\circ} \mathrm{F}(\mathrm{R}-15 \mathrm{ci})$ \\
\hline Window U-factor & 0.587 \\
\hline Window SHGC* & 0.39 \\
\hline WWR** & $30 \%$ \\
\hline \multicolumn{2}{|l|}{ Lighting System } \\
\hline Lighting power density & $1.0 \mathrm{w} / \mathrm{ft}^{2}$ \\
\hline \multicolumn{2}{|l|}{ Mechanical System } \\
\hline Chiller type and COP & Screw chiller, 5.0 COP \\
\hline Boiler eff & $80 \%$ Ec $(75 \% \mathrm{Et})$ \\
\hline SWH eff & $80 \% \mathrm{Et}$ \\
\hline $\begin{array}{l}* \text { SHGC = solar heat gain coefficient } \\
* * \mathrm{WWR}=\text { window to wall ratio }\end{array}$ & $\begin{array}{l}\mathrm{Ec}=\text { Combustion efficiency } \\
\mathrm{Et}=\text { Thermal efficiency }\end{array}$ \\
\hline
\end{tabular}




\section{Development of Service Hot Water Load Estimates}

The service hot water load was calculated based on the estimated number of rooms in the hotel using the hotel data from Table 4, peak hot water consumption per person of 4 gallons per hour from ASHRAE (ASHRAE 1999). For sizing purposes, a $40^{\circ}$ entering temperature was assumed. The delivery water temperature was assumed to be $140^{\circ} \mathrm{F}$ (The ASHRAE flow rates are assumed to be representative of the hot water delivered at the water heater delivery temperature).

This results in a design hot water flow rate of $22.3 \mathrm{gpm}$ per hotel wing, and a net hot water design load of $1.11 \mathrm{million} \mathrm{Btu} / \mathrm{h}$. This is in excess of the $1,000,000 \mathrm{Btu} / \mathrm{h}$ that would trigger the heat recovery for service water heating code requirement.

Default building use schedules, including hot water use schedules from DOE2.2 for the hotel were used in modeling the overall hot water load. Figure 1 shows the DOE2.2 hot water load schedule for a weekday. It should be noted that because the inlet water temperature to the heat recovery system varies during the year, the peak load for system design purposes may need to be typically higher in the winter than in the summer.

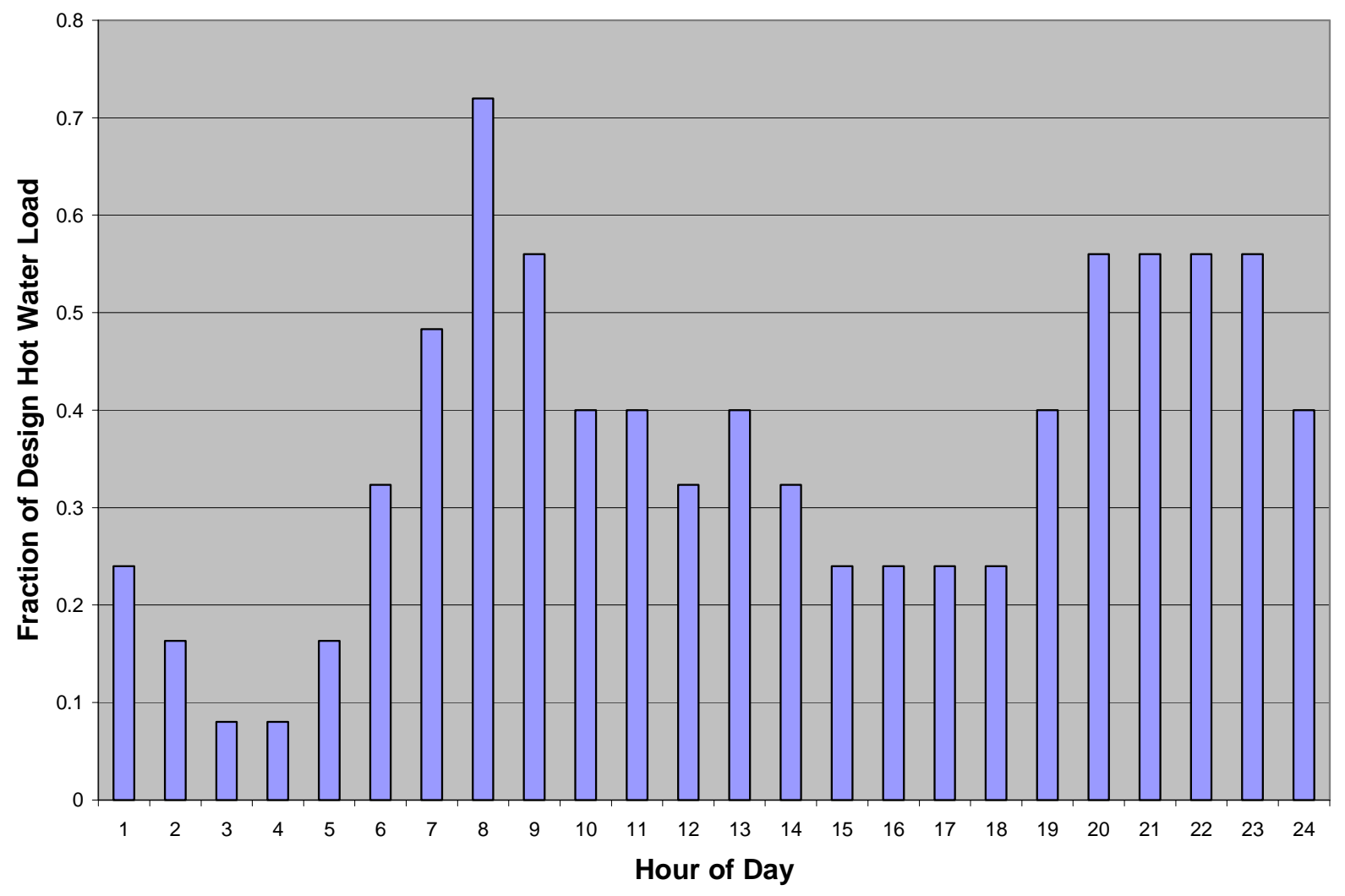

Figure 1. Hot Water Load Profile from DOE2.2, Hotel 
An estimate of the size for the water heating system was developed using the ASHRAE Applications Handbook information, looking at the tradeoff between storage and heat rate for the water heater system, as well as information provided on-line by A.O. Smith (2004), which suggests a minimum storage for 300-350 hotel units of 700 gallons total. The final design implemented assumed 1,000 gallons of water storage, implemented using two 500-gallon commercial water heaters. The combined UA for this system, used for estimating standby loss, is approximately $88 \mathrm{Btu} / \mathrm{h}-{ }^{\circ} \mathrm{F}$ based on ASHRAE $90.1-1999$ service water heating. 


\section{Base Building Simulation}

The hotel wing was simulated using the default building schedules from DOE2.2 as discussed previously, and using New York City typical meteorological year (TMY2) weather data. Figures 2 and 3, and Table 6 , show the month-by-month energy consumption for the building end-uses. The cooling and heat rejection equipment was sized to meet the peak capacity required for these systems during the annual simulation, with a $20 \%$ additional sizing allowance applied. As noted previously, the peak cooling capacity selected for this one wing, at 1.67 million Btu/h $\left(729 \mathrm{ft}^{2} / \mathrm{ton}\right)$ was significantly lower than what would trigger the IECC2003 requirement. This may be partially caused by the significantly lower lighting levels assumed for hotel buildings in the IECC than those in previous building codes, as well as the result of the New York climate being somewhat cooler than that likely envisioned by the framers of the heat recovery requirement. Nevertheless, it was felt that doing the analysis on only one wing of the building would still provide a reasonable, if possibly conservative assessment of the economics for a simple heat recovery application.

It must also be noted that for this simple building, the chiller load was only seen to be significant for 5 months of the year. It is not clear how well this represents what might be thought of as "typical" loads for this size hotel building. However, because the IECC would require the use of water economizers to meet $100 \%$ of cooling loads when outside air temperatures are less than $50^{\circ} \mathrm{F}$ dry bulb temperatures, $45^{\circ} \mathrm{F}$ wet bulb temperatures, chillers under these temperatures could effectively be scheduled off. The relatively fewer months of chiller operation compared to warmer climates would be expected to negatively impact the cost-effectiveness for a service hot water heat recovery system compared with a warmer climate.

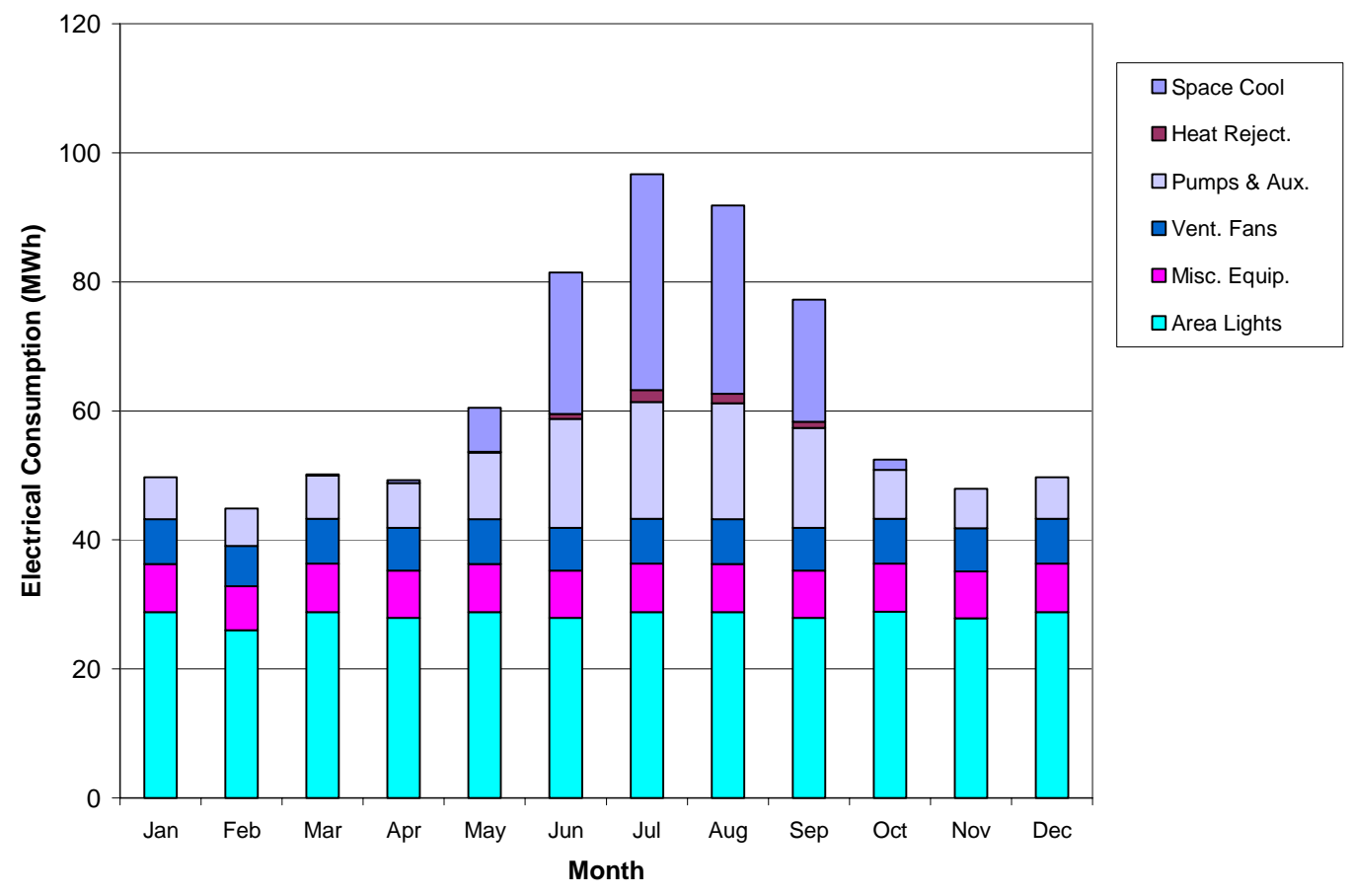

Figure 2. Electrical Energy Consumption for Base Hotel Building, by End Use. 


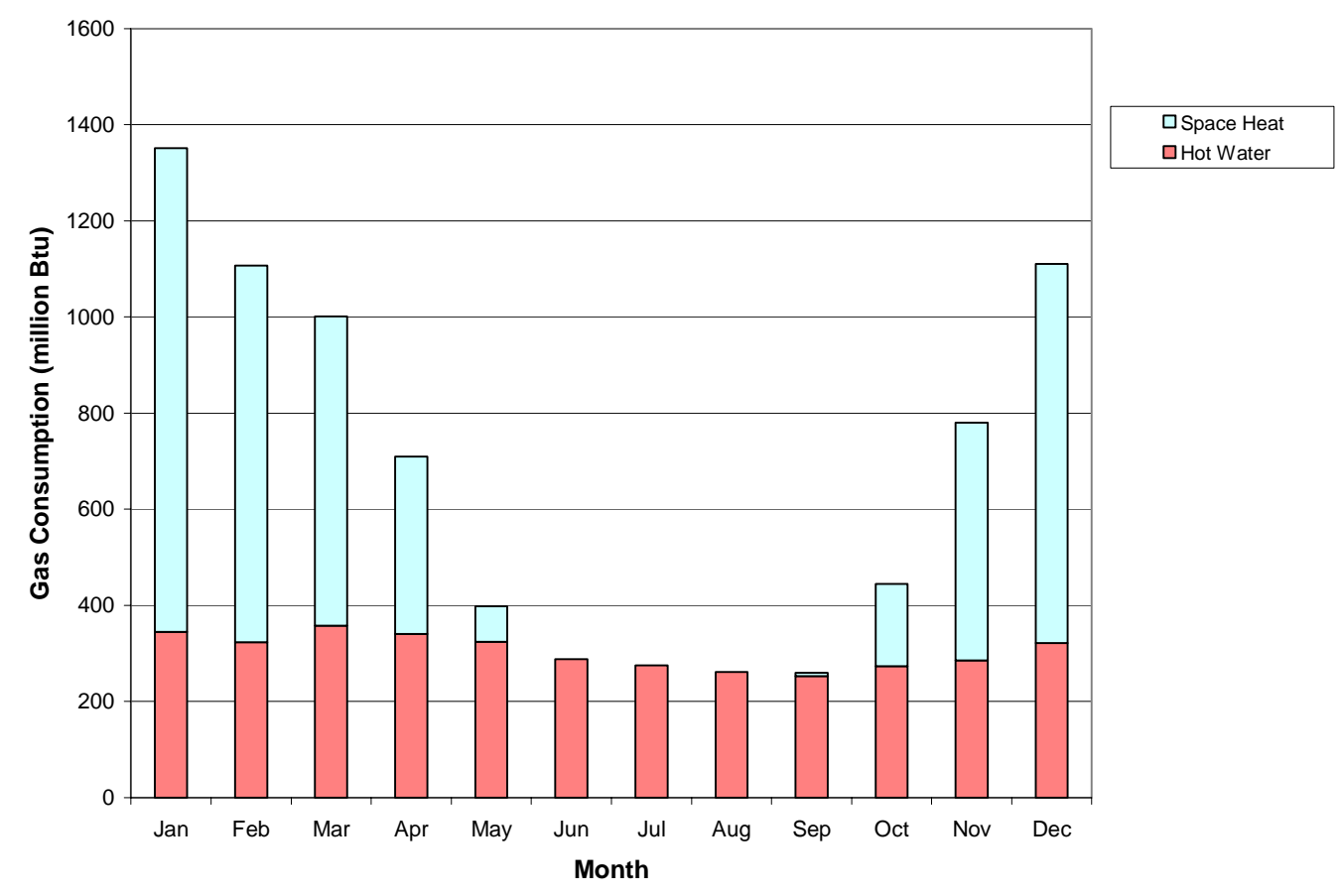

Figure 3. Natural Gas Energy Consumption for Base Hotel Building, by End Use.

Table 6 Energy Consumption for Base Hotel Building, by End Use.

\begin{tabular}{|c|c|c|c|c|c|c|c|c|c|c|c|c|c|}
\hline $\begin{array}{c}\text { Electric } \\
\text { Consumption } \\
(\mathrm{MWh})\end{array}$ & Jan & Feb & Mar & Apr & May & Jun & Jul & Aug & Sep & Oct & Nov & Dec & Total \\
\hline Space Cool & 0.0 & 0.0 & 0.2 & 0.5 & 6.9 & 21.9 & 33.5 & 29.1 & 18.9 & 1.6 & 0.0 & 0.0 & 112.5 \\
\hline Heat Reject. & 0.0 & 0.0 & 0.0 & 0.0 & 0.1 & 0.8 & 1.8 & 1.5 & 0.9 & 0.0 & 0.0 & 0.0 & 5.1 \\
\hline Vent. Fans & 6.9 & 6.2 & 6.9 & 6.7 & 6.9 & 6.7 & 6.9 & 6.9 & 6.7 & 6.9 & 6.7 & 6.9 & 81.4 \\
\hline Pumps \& Aux. & 6.5 & 5.8 & 6.7 & 6.9 & 10.3 & 16.9 & 18.1 & 18.0 & 15.5 & 7.6 & 6.1 & 6.4 & 124.7 \\
\hline Misc. Equip. & 7.5 & 6.8 & 7.5 & 7.3 & 7.5 & 7.3 & 7.5 & 7.5 & 7.3 & 7.5 & 7.3 & 7.5 & 88.6 \\
\hline Area Lights & 28.8 & 26.0 & 28.8 & 27.9 & 28.8 & 27.9 & 28.8 & 28.8 & 27.9 & 28.8 & 27.9 & 28.8 & 339.2 \\
\hline Total & 49.7 & 44.9 & 50.1 & 49.3 & 60.5 & 81.5 & 96.7 & 91.8 & 77.2 & 52.4 & 47.9 & 49.7 & 751.6 \\
\hline $\begin{array}{l}\text { Gas } \\
\text { Consumption } \\
\text { (million Btu) }\end{array}$ & Jan & Feb & Mar & Apr & May & Jun & Jul & Aug & Sep & Oct & Nov & Dec & Total \\
\hline Space Heat & 1006.6 & 783.8 & 642.7 & 369.7 & 74.2 & 0.0 & 0.0 & 0.0 & 7.6 & 171.7 & 493.9 & 789.0 & 4339.3 \\
\hline Hot Water & 344.3 & 323.2 & 358.0 & 339.9 & 324.0 & 288.3 & 274.9 & 261.0 & 252.1 & 273.0 & 285.6 & 320.9 & 3645.3 \\
\hline Total & 1350.9 & 1107.0 & 1000.7 & 709.7 & 398.1 & 288.3 & 274.9 & 261.0 & 259.8 & 444.8 & 779.6 & 1109.9 & 7984.6 \\
\hline
\end{tabular}




\section{Condenser Heat Rejection and Service Hot Water Loads}

The following hourly data were extracted from the DOE2.2 base case simulation

Chiller Plant Cooling Load

Chiller Heat Rejection

Chiller Electrical Power Consumed

Chilled Supply Water Temperature

Entering Condenser Water Temperature

Service Hot Water Load

Service Hot Water Make-up Water Temperature

Service Hot Water Make-up Flow Rate

Cooling Tower Heat Rejection Load

Cooling Tower Fan Energy

In addition, the hourly Leaving Condenser Water Temperature was calculated from the total heat rejection and the Entering Condenser Water Temperature, and loop flow rate. A constant flow rate was assumed for the chiller condenser during operation.

\section{Heat Recovery Strategy}

Several common strategies for heat recovery were examined from the outset of this task based on discussions with consulting engineers and a review of ASHRAE's recently published Application Guide for Chiller Heat Recovery. (ASHRAE 1999b). The most common strategies were deemed to be 1) a separate condenser bundle on the screw chiller, but operating at typical heat rejection temperatures $\left(<110^{\circ} \mathrm{F}\right)$ for a chiller; 2$)$ a separate, smaller, heat recovery chiller servicing the main cooling loop and rejecting heat at a high temperature (Scroll chiller, $130^{\circ} \mathrm{F}$ heat rejection); and 3) a simple heat exchange process between the condenser water and the incoming make-up water. While both strategy (1) and (2) were deemed likely to result in high total energy savings, the relatively few hours of chiller operation per year suggested that a simpler strategy may be more cost effective and would satisfy the minimum requirement of the IECC to provide preheat of the peak hot water consumption to $85^{\circ} \mathrm{F}$ during peak cooling periods.

A simple plate and frame heat exchanger, operating between the exiting condenser water temperature and the make-up supply water was assessed (see Figure 4). The heat exchanger was sized to provide a $5^{\circ} \mathrm{F}$ approach to the condenser water temperature at peak design hot water flow. Because the make-up service hot water flow is typically much less than the design flow during most of the year, a closer approach temperature would be achieved during most of the yearly operation. 


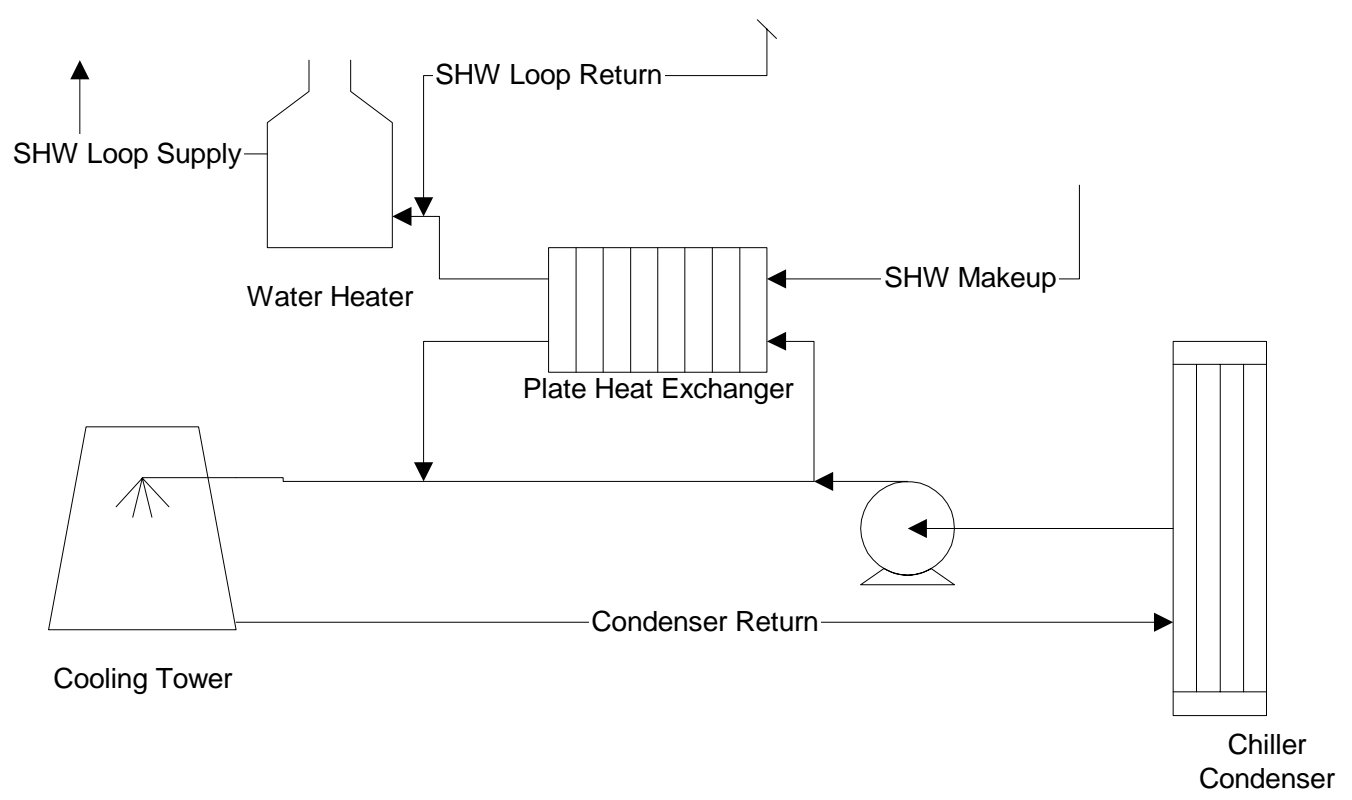

Figure 4. Schematic of Service Heat Recovery System

A model of the heat exchange process using the NTU (number of transfer units) methodology was developed based on a preliminary sizing methodology for plate and frame heat exchangers outlined by Haslego (Haslego 2002). A spreadsheet implementation of this methodology was used to provide for approximate heat exchanger sizing, as well as generate first cost estimates as a function of the inlet conditions (temperatures and flow rates) and desired approach temperatures.

A similar heat recovery model, based on the heat exchanger size (in NTU) from the above spreadsheet was implemented in a spreadsheet containing the hourly data output from the simulation. This allowed calculation of the total heat recovered by the heat exchanger when allowing for the hourly varying makeup water flow and available condenser heat and condenser outlet temperature. Separate calculations of additional pumping power for the SHW and condenser sides of the heat exchanger were also implemented in the hourly spreadsheet.

At design conditions, the total heat rejected by the chiller is vastly greater than the peak hot water need. Some limited optimization was done to examine tradeoffs between maximum amount of heat recovery possible (achieved through larger heat exchangers and use of total condenser water flow rates) and simple systems that only used a fraction of the total condenser water (and a fraction of the available condenser heat) for the heat exchange process. This analysis suggested that utilizing approximately $25 \%$ of the condenser flow rate as input to the SHW heat exchanger provided a high ratio of the heat-recovery benefit to total pumping-cost on an annual basis (assuming a 15 psi pressure drop across the heat exchanger). The resulting sizing specifications of the heat exchange system are shown in Appendix A. The approximate cost of a stainless steel heat exchanger is also shown based on the cost estimating approach provided by Haslego.

After the original analysis was used to determine an optimal condenser flow rate, a second, manufacturer's heat exchanger sizing tool (Mueller 2004) was used to more formally size a heat 
exchanger with double wall vent. This second sizing, also shown in Appendix B, resulted in a heat exchanger with approximately three times the total plate area $\left(70.5 \mathrm{ft}^{2}\right.$ versus $23.6 \mathrm{ft}^{2}$ from the Haslego method.). This is believed to be primarily a result of the lower rate of heat transfer caused by the double wall vented design. This second design did, however, result in lower total pressure drop through the heat exchanger (5.4 psig versus 15 psig specified in the original Haslego design). The final energy savings analysis was based on this second heat exchanger design.

Hourly energy savings for the service hot water heat recovery system were calculated based on dividing the hourly heat recovered by the system by the assumed thermal efficiency for the water heater. Pumping costs were based on the design pressure drops using the manufacturer's sizing tool. For this analysis, a constant thermal efficiency of $80 \%$ was assumed for the water heating system.

\section{Impact on Chiller Performance}

Because only standard condenser water temperatures were assumed for this analysis, no chiller efficiency degradation could be attributed to this heat recovery process. At very low chiller loads, there may be some performance gains because the entering condenser water temperature could be pre-cooled below the design entering temperature using the SHW make-up water. Additional savings for the simple heat exchanger strategy could be made through reduction of the condenser flow rate to increase the condenser leaving water temperature and the subsequent heat recovery. This would come at some reduction in the overall chiller performance, but would also reduce the load and energy consumption of the cooling tower (see below).

\section{Impacts to Heat Rejection Equipment}

Because the heat recovery removes heat from the chiller heat rejection loop, less heat rejection occurs at the cooling tower, reducing tower fan run time. In instances where large quantities of heat are removed (for instance, using a dedicated heat recovery chiller to meet $70 \%$ or more of summer hot water loads), this can be significant savings. To account for that effect in this study, the hourly tower fan energy was reduced by the same ratio as the condenser loads to the tower after accounting for heat recovery. For example, if $10 \%$ of the condenser load was used for heat recovery, the cooling tower fan energy was reduced by $10 \%$ for that hour. This assumes the towers use multiple cells and multiple fan speeds (required under IECC2003).

\section{Energy Cost Savings}

Annual energy cost savings for the heat recovery system were estimated at approximately $\$ 2400 / y$ r based on monthly average New York State gas and electricity prices for 2003. (Energy Information Administration 2004). Table 7 shows expected monthly energy and energy cost savings for the heat recovery option examined. 
Table 7. Building Energy Impacts from Heat Recovery

\begin{tabular}{|c|c|c|c|c|c|c|}
\hline \multirow[t]{2}{*}{ Month } & \multirow{2}{*}{$\begin{array}{l}\text { Gas } \\
\text { (Million } \\
\text { Btu) } \\
\text { SHW }\end{array}$} & \multicolumn{2}{|c|}{$\begin{array}{l}\text { Electricity } \\
(1000 \text { kWh) }\end{array}$} & \multirow{2}{*}{$\begin{array}{l}\text { Electricity } \\
\text { (\$/kWh) }\end{array}$} & \multirow{2}{*}{$\begin{array}{l}\text { Gas } \\
(\$ / \text { million } \\
\text { Btu })\end{array}$} & \multirow{2}{*}{$\begin{array}{l}\text { Energy } \\
\text { Cost } \\
\text { Savings } \\
\text { (\$) }\end{array}$} \\
\hline & & Pump & Tower & & & \\
\hline Jan & 0.00 & 0.00 & 0.00 & 11.1 & 8.03 & 0 \\
\hline Feb & 0.00 & 0.00 & 0.00 & 11.8 & 8.53 & 0 \\
\hline Mar & $(0.90)$ & 0.01 & $(0.00)$ & 12.6 & 10.01 & 8 \\
\hline Apr & (2.23) & 0.03 & $(0.00)$ & 13.1 & 9.70 & 18 \\
\hline May & $(31.14)$ & 0.18 & $(0.03)$ & 13.0 & 9.48 & 275 \\
\hline Jun & $(84.72)$ & 0.36 & $(0.12)$ & 13.6 & 9.15 & 742 \\
\hline Jul & (96.15) & 0.38 & $(0.20)$ & 14.4 & 8.27 & 770 \\
\hline Aug & $(78.09)$ & 0.38 & $(0.15)$ & 14.5 & 7.80 & 577 \\
\hline Sep & $(56.27)$ & 0.33 & $(0.09)$ & 14.3 & 7.91 & 412 \\
\hline Oct & $(7.16)$ & 0.07 & $(0.00)$ & 13.8 & 7.99 & 47 \\
\hline Nov & 0.00 & 0.00 & 0.00 & 12.4 & 8.61 & 0 \\
\hline Dec & $(0.03)$ & 0.00 & 0.00 & 12.1 & 9.34 & 0 \\
\hline Annual & -356.70 & 1.74 & -0.60 & & & 2849 \\
\hline
\end{tabular}

The estimated hot water energy savings for this system was approximately $10 \%$ of the hot water energy used in the base case building, or approximately $3.4 \%$ of the site energy use of the building.

\section{Installed Cost}

The first cost of the heat recovery system was estimated at $\$ 18,000$ based on material and installation costs estimates shown in Appendix A. The material cost of the primary component, a plate and frame heat exchanger, was based on a quote from a manufacturer's representative, attached in Appendix B. The balances of system costs were developed from Means (RS Means 2004). An average location factor increase of $113 \%$ was applied to the Means Cost estimates, based on the average of the New York location factors reported.

Installation, piping and valves costs are largely unknown and would be specific to each individual installation. The costs provided here are approximate, based on the assumption that the domestic water feed line and the chiller condenser flow loop have been designed to be within relatively close proximity at some point in the building. Allowances for $40 \mathrm{ft}$ of piping on either side of the heat exchanger have been provided.

\section{Estimated Payback}

Based on the annual energy savings of $\$ 2850$ and the $\$ 18,000$ installed cost of the service hot water heat recovery system, the simple payback for the system was 6.3 yrs. This is under the 10 -year payback threshold established for the state of New York. 


\section{Conclusion}

The analysis presented suggested that the simple condenser heat exchanger could provide a cost-effective way to meet the IECC2003's heat recovery for service water heating requirement in a typical hotel application. It is expected that it would also be cost-effective in inpatient hospital applications, one of the other likely building types to which this requirement would apply. It would also be expected to be costeffective in multifamily residential buildings, where central water-cooled cooling might be used.

The analysis of buildings also suggested that there may be other building types, such as very large offices, which may meet the criteria under the IECC, but whose load profiles for hot water use may be very different than that of the more common hotel/motel. No actual analysis was done to examine the costeffectiveness for these buildings.

It is recognized that other heat recovery strategies may be more cost-effective and may result in greater savings in this or in similar applications, and this report should not be interpreted as recommending one heat recovery strategy over another. 


\section{References}

A.O. Smith. 2004. Hot Water Requirements - Motels and Hotels.

http://www.hotwater.com/PDFSpecSheets/B105.pdf, accessed June 2004

ASHRAE. 1999. ASHRAE Applications Handbook, American Society of Heating, Refrigerating, and Air Conditioning Engineers, Atlanta, Georgia.

ASHRAE . 1999b. Application Guide for Chiller Heat Recovery. American Society of Heating, Refrigerating, and Air Conditioning Engineers, Atlanta, Georgia.

ASHRAE 90.1. 1999.

ASHRAE 90.1. 2001.

Bell. 2000. HVAC Equations, Data, and Rules of Thumb. McGraw Hill, New York.

DOE. 2000. Screening Analysis for EPACT Covered Commercial HVAC and Water Heating

Equipment. U.S. Department of Energy, Washington, D.C.

Energy information Administration (EIA). 1997. 1995 Commercial Building Energy Consumption Survey. U.S. Department of Energy Energy Information Administration, Washington, D.C. http://www.eia.doe.gov/emeu/cbecs/

Energy Information Administration (EIA). 2004. Electric Power Monthly, June 2004, EIA website: http://tonto.eia.doe.gov/FTPROOT/electricity/epm/02260406.pdf, U.S. Department of Energy. Washington D.C.

Haslego. 2002. Designing Plate-and-Frame Heat Exchangers. CEP Magazine, September.

Hirsch. 2003. DOE2.2 Building Energy Use and Cost Analysis Program. (http://www.doe2.com/)

George. 2003 Sizing water heaters for hotels and motels. PMEngineer, Vol 3. Viewable online at http://www.pmengineer.com/CDA/ArticleInformation/features/BNP_Features_Item/0,2732,93793,00.h $\underline{\mathrm{tml}}$ accessed May 2004

IECC. 2003. International Energy Conservation Code, International Code Council, Inc. Country Club Hills, Ilinois.

Meyer. 2001. Hot Water for the Road. Energy Systems. October.

http://www.esmagazine.com/CDA/ArticleInformation/features/BNP Features Item/0,2503,66234,00.h $\underline{t m l}$, accessed May 2004

Mueller. 2004. Online Accu-Therm Plate and Frame Heat Exchanger Sizing Tool and Engineering Support. (http://www.muel.com/products/heattransfer/plate/, accessed August 2004) 
R.S. Means. 2004. Mechanical Cost Data, $27^{\text {th }}$ Annual Edition. RS Means, Kingston, Massachusetts. 


\section{Appendix A}

\section{Design Parameters for Plate Heat Exchanger}




\section{Appendix A Design Parameters for Plate Heat Exchanger}

Table A-1 Design Parameters for Plate Heat Exchanger System (Haslego)

\begin{tabular}{|c|c|}
\hline \multicolumn{2}{|l|}{ Service Hot Water Side } \\
\hline Entering water temperature at design $(F)$ & 60 \\
\hline Maximum design SHW water flow (gpm) & 22.3 \\
\hline Approach (F) & 5 \\
\hline Acceptable SHW pressure drop at design (psid) & 15 \\
\hline Heat capacity (Btu/F) & 11125 \\
\hline \multicolumn{2}{|l|}{ Condenser Side } \\
\hline Condenser water inlet temp at design $(F)$ & 95 \\
\hline Condenser water flow (gpm) & 96.2 \\
\hline Heat capacity (Btu/F) & 47920 \\
\hline \multicolumn{2}{|l|}{ Acceptable condenser pressure drop at design (psid) } \\
\hline \multicolumn{2}{|l|}{ Design } \\
\hline $\mathrm{Cmin} / \mathrm{Cmax}$ at design & 0.23 \\
\hline Leaving SHW temp at design & 90 \\
\hline Leaving condenser water temp & 88.0 \\
\hline Total heat transferred & 333760 \\
\hline Eff & 0.86 \\
\hline Log mean temperature differential & 13.36 \\
\hline NTU_condenser & 0.52 \\
\hline NTU_shw & 2.25 \\
\hline h_condenser, $15 \mathrm{psi}\left(\mathrm{Btu} / \mathrm{hr}-\mathrm{ft}^{2}-{ }^{\circ} \mathrm{F}\right)$ & 2800 \\
\hline \multirow[t]{2}{*}{ h_shw, $15 \mathrm{psi}\left(\mathrm{Btu} / \mathrm{hr}^{\circ} \mathrm{ot}^{2}-{ }^{\circ} \mathrm{F}\right)$} & 2500 \\
\hline & Type 316 \\
\hline Plate type & $\begin{array}{l}\text { Stainless, } \\
0.5 \mathrm{~mm}\end{array}$ \\
\hline$U\left(B t u / h-\mathrm{ft}^{2}-{ }^{\circ} \mathrm{F}\right)$ & 1057 \\
\hline \multicolumn{2}{|l|}{$Q=$ UA LMTD } \\
\hline Area $\left(\mathrm{ft}^{2}\right)$ & 23.63 \\
\hline $\mathrm{UA}\left(\mathrm{Btu} / \mathrm{h}-{ }^{\circ} \mathrm{F}\right)$ & 24980 \\
\hline \multicolumn{2}{|l|}{ Cost } \\
\hline Cost $(\$)$ & 1881 \\
\hline
\end{tabular}


Table A-2 Final Double Wall-Vented Plate Heat Exchanger Specification Sheet used in Energy Savings

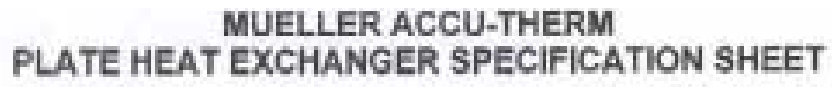

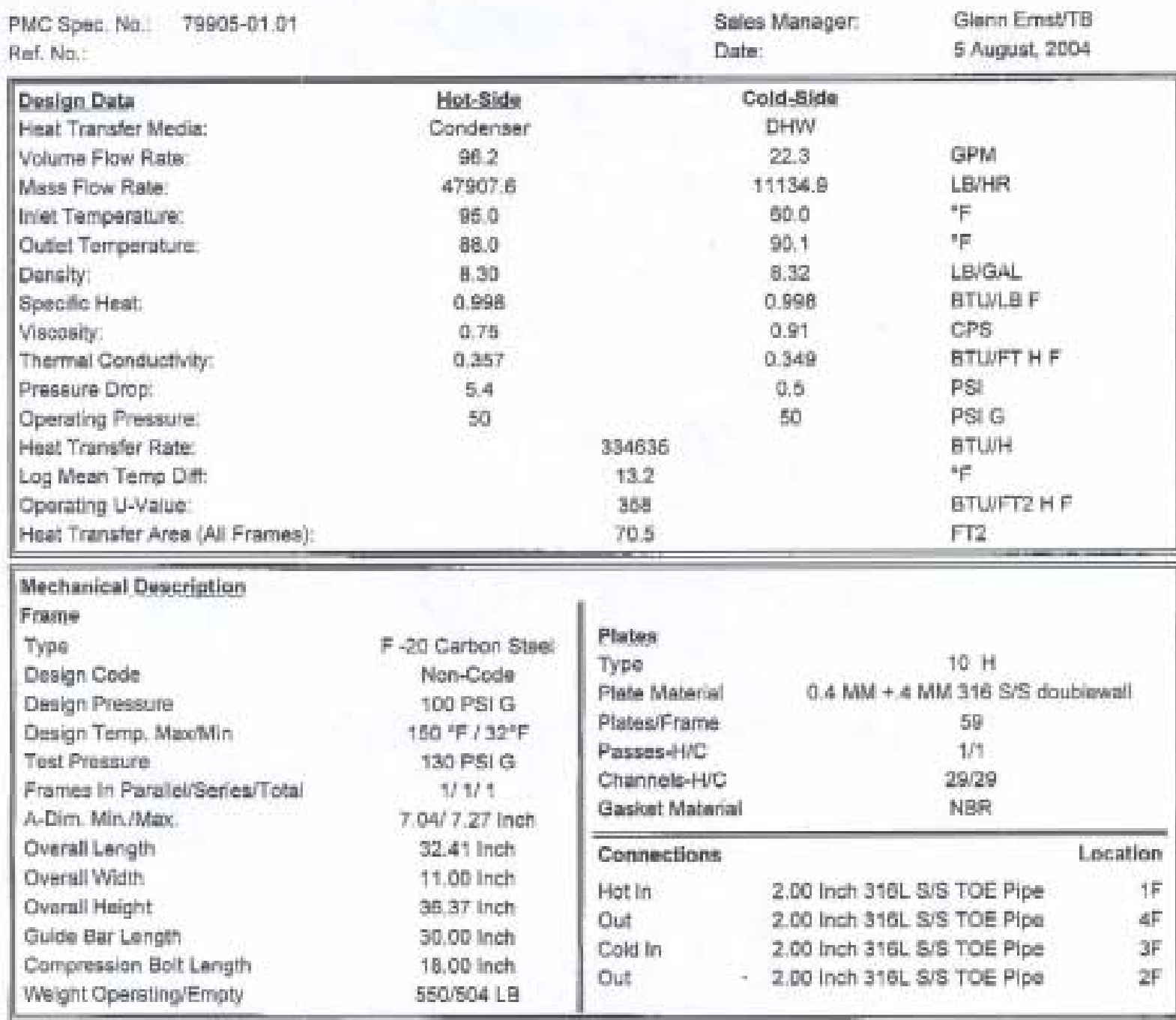

Notes:

Aluminum shroud included

The purchaser of the equipment bears total responsibility far suitability of use of al materiais in this applicason.

We may hare sssumed sorne design values. If they diffor from your requirements, a new design may be necessary. 
Appendix B

\section{Estimated Costs for Heat Recovery System}




\section{Appendix B Estimated Costs for Heat Recovery System}

Table B-1 Material, Labor, and Total Estimated Installation Cost for Heat Recovery System

\begin{tabular}{|c|c|c|c|c|c|}
\hline Material & Qty & $\begin{array}{l}\text { Material Cost } \\
\text { (\$) }\end{array}$ & $\begin{array}{l}\text { Labor } \\
\text { (\$) }\end{array}$ & $\begin{array}{l}\text { Total } \\
\text { (\$) }\end{array}$ & $\begin{array}{l}\text { Total with } \\
\text { Overhead \& } \\
\text { Profit } \\
\text { (\$) }\end{array}$ \\
\hline $\begin{array}{l}\text { Plate and frame heat } \\
\text { exchanger } \mathrm{UA}=358 \mathrm{Btu} / \mathrm{ft}^{2}- \\
\mathrm{h}-{ }^{\circ} \mathrm{F}\end{array}$ & 1 & 7,500 & 215 & 7,715 & 9644 \\
\hline $\begin{array}{l}\text { Pipe, black steel, 2-in. dia, } 40 \\
\mathrm{ft} \text { with couplings and hangers }\end{array}$ & 1 & 145.6 & 356 & 501.6 & 696 \\
\hline 2-in. iron elbows & 4 & 34 & 126 & 160 & 228 \\
\hline 6-in. pipe $\mathrm{T}$, reducing & 2 & 840 & 444 & 1284 & 1590 \\
\hline 2-in. gate valve, bronze & 4 & 332 & 116 & 448 & 536 \\
\hline 2-in. balancing valve, bronze & 1 & 355 & 40 & 395 & 450 \\
\hline 2-in. strainers, Y-type & 2 & 55 & 80 & 135 & 179 \\
\hline $\begin{array}{l}\text { Pipe, copper, 2-in. dia, } 40 \mathrm{ft} \text {, } \\
\text { type L }\end{array}$ & 1 & 182 & 302 & 484 & 652 \\
\hline 2-in. copper elbows & 4 & 28.4 & 116 & 144.4 & 204 \\
\hline Condenser loop pump, $2 \mathrm{hp}$ & 1 & 1250 & 248 & 1498 & 1750 \\
\hline Total & & 10,722 & 2,043 & 12,765 & 15,929 \\
\hline \multicolumn{5}{|c|}{ Total with Average New York Location Factor Markup (113\%) } & $\mathbf{1 7 , 9 9 9}$ \\
\hline
\end{tabular}

